\title{
Succession of bacterial grazing defense mechanisms against protistan predators in an experimental microbial community
}

\author{
Michaela M. Salcher ${ }^{1}$, Jakob Pernthaler ${ }^{2}$, Roland Psenner ${ }^{1}$, Thomas Posch ${ }^{1, *}$ \\ ${ }^{1}$ Institute of Zoology and Limnology, University of Innsbruck, Technikerstraße 25, 6020 Innsbruck, Austria \\ ${ }^{2}$ Max Planck Institute for Marine Microbiology, Celsiusstraße 1, 28359 Bremen, Germany
}

\begin{abstract}
We studied the effects of 2 bacterivorous protistan predators on the phenotypic and taxonomic successions of an experimental bacterial community growing in continuous culture with the cryptophyte Cryptomonas phaseolus. Two predators were inoculated to the cultivation system, the mixotrophic flagellate Ochromonas sp., an interception feeder, and the filter-feeding heterotrophic ciliate Cyclidium glaucoma. The system was sampled every second day over a period of 3 mo. The competition between algae and bacteria for limiting phosphorus $\left(20 \mu \mathrm{g} \mathrm{P}^{-1} \mathrm{~d}^{-1}\right)$ was reflected in pronounced fluctuations of the ratio of algal versus bacterial biomass. High grazing pressure exerted on bacteria by the flagellate led to a strong decrease of bacterial abundance and biomass, with only few cells left freely dispersed. A succession of various grazing-resistant morphologies was observed, such as microcolonies, large aggregates and filaments. A population affiliated with Aquabacterium sp. formed grazing-resistant co-colonies with a Caulobacter spp., indicating that these 2 bacteria might find a common refuge from protistan grazing within aggregates or biofilms. During the course of the experiment these large colonies were succeeded by grazing-protected morphotypes related to the Flexibacter sancti-Flavobacterium ferrugineum lineage of the Sphingobacteriales. In contrast, the ciliate induced only a slight reduction of bacterial abundance, and bacteria even recovered to higher than original numbers after a few weeks. However, pronounced successions of microbial populations were also observed in the presence of the ciliate.
\end{abstract}

KEY WORDS: Bacteria-algae interaction · Bacterial assemblage composition · Bacterial succession · Continuous cultivation system · Cyclidium glaucoma · Grazing defense mechanism · Ochromonas sp. Predator-prey interaction

Resale or republication not permitted without written consent of the publisher

\section{INTRODUCTION}

Grazing by bacterivorous protists can affect major phenotypic and physiological characteristics and the species composition of a bacterial assemblage. Changes in bacterial morphology due to protistan grazing are well documented (for review see Hahn \& Höfle 2001, Jürgens \& Matz 2002). In contrast, fewer studies have investigated the relationship between genotypic and phenotypic assemblage changes, and different bacteria seem to follow contrasting strategies to respond to a particular predator. Some bacterial phylotypes show pronounced phenotypic plasticity, as reflected by an increase or decrease in size, the formation of filaments or the establishment of microcolonies or aggregates (Hahn \& Höfle 2001, Hahn et al. 2004).

Fluorescence in situ hybridization (FISH) is a powerful tool to simultaneously study the phenotypic characteristics and phylogenetic identity of cells in mixed bacterial assemblages. Using FISH, grazing-induced changes in bacterial assemblage composition have been repeatedly observed both in the laboratory (Pernthaler et al. 1997, 2001, Šimek et al. 1997, Posch et al. 2001) and in field studies (Jürgens et al. 1999, Šimek et al. 1999, 2001a,b, 2003, Langenheder \& Jürgens 2001, Gasol et al. 2002). Such shifts could be caused directly 
by size-selective feeding, but also indirectly, for instance as a result of a change in the abundance of bacterial competitors or in the nutrient release by predators (see Fig. 5 in Jürgens \& Matz 2002).

In most of the aforementioned studies, changes in bacterial assemblages caused by protistan grazing have been induced experimentally and they were studied over very short time periods (hours and days). In contrast, our knowledge about successions of distinct bacterial genotypic populations or of their grazing defense mechanisms in response to continuous protistan grazing pressure is still scarce (Masín et al. 2003). There are first indications that grazing-induced shifts of bacterial assemblages are not only linked to the differential vulnerability of individual bacterial populations, but at the same time to the dominance of different predator species (Posch et al. 1999, Pernthaler et al. 2001). Likely, grazing by bacterivorous protists does not provoke a simple binary (yes/no) answer. Instead, the specific characteristics of the grazing regime (e.g. different nutrition modes, different size selectivity, varying generation times of predators, assemblage composition of predators) will be of relevance for the development of any diverse bacterial assemblage. Individual bacterial genotypes might thus be characterized by different levels of vulnerability to grazing per se, but at the same time the grazinginduced responses might be strongly influenced by the characteristics of protistan feeding.

We studied the long-term interactions between a mixed experimental bacterial assemblage and 2 protistan predators with different feeding behavior. Exudates of the autotrophic alga Cryptomonas phaseolus were used as a natural carbon source by the accompanying bacteria. The sampling interval was adapted to match the calculated doubling time of organisms as determined by the dilution rate (theoretically 40 bacterial generations).

Our hypotheses were (1) that grazing by 2 protistan species with different feeding modes will cause different responses of the bacterial community, e.g. in abundance, size, biovolume and bacterial assemblage composition; (2) that there will be successions of different bacterial genotypic populations; and (3) that the bacterial assemblage will show a succession of grazing protection mechanisms when exposed to predation over an extended period of time.

\section{MATERIALS AND METHODS}

Continuous cultivation system. The experiment was performed in a 2-stage continuous cultivation system. Details of the setup have been described earlier in Posch et al. (1999). Briefly, the first stage (2.4 l, further described as I-Stage) was inoculated with the cryptophyte Cryptomonas phaseolus and its accompanying mixed bacterial assemblage (see Pernthaler et al. 2001 for a phylogenetic analysis of dominant community members). The algae were grown on WC-medium (Guillard \& Lorenzen 1972) with a decreased phosphorus content of $50 \mu \mathrm{g} \mathrm{P} \mathrm{l}^{-1}$ at $18^{\circ} \mathrm{C}$ in a light:dark rhythm of 16:8 h. Initially, the system was tested with distilled water and autoclaved before inoculation of the $C$. phaseolus and bacteria stockcultures. It was maintained as batch culture for $3 \mathrm{~d}$, and afterwards as a chemostat for $79 \mathrm{~d}$ with a dilution rate of $0.39 \mathrm{~d}^{-1}$ (corresponding to a P-loading of $19.5 \mu \mathrm{g} \mathrm{P} \mathrm{l}^{-1} \mathrm{~d}^{-1}$ ). Three replicate vessels (780 $\mathrm{ml}$ each) were used as second stages. Two predator species were inoculated in the second stage vessels at Day 7 , the mixotrophic flagellate Ochromonas sp. strain DS, an interception feeder (further described as II-Och), and the heterotrophic scuticociliate Cyclidium glaucoma, a filter feeder (further described as II-Cyc). The third vessel served as control without any predators (further described as II-Con). The dilution rate of the second stage vessels was $0.35 \mathrm{~d}^{-1}$. Protists were precleaned from bacteria by washing and filtering the stockcultures with sterilized WC-medium onto $3 \mu \mathrm{m}$ filters and inoculating them in C. phaseolus stockculture to remove their accompanying bacteria. This process was repeated 3 times within a month before the experiment was started.

Samples were taken every second day over a period of $79 \mathrm{~d}$ in order to follow the theoretical generation time of organisms, given by the dilution rate of the second stage. Sampling was carried out with a special construction to avoid contamination by other bacteria, which is particularly important for longterm experiments. Only a small volume of each vessel was removed every second day $(75 \mathrm{ml},<10 \%$ of the total vessel volume), so that there was minimal disturbance of the chemostat system by sampling. Counting and sizing of organisms was done within $1 \mathrm{~d}$ after sampling.

Determination of bacterial and protistan abundance and biomass. Subsamples of $40 \mathrm{ml}$ were fixed with alkaline Lugol's solution $(0.5 \%$ final concentration), followed by formaldehyde (3\% final concentration), and decolorized with several drops of sodium thiosulfate (Sherr \& Sherr 1993). Samples were stained with DAPI $\left(4^{\prime}, 6^{\prime}\right.$-diamidino-2'-phenylindole, $6.7 \mu \mathrm{g} \mathrm{ml}^{-1}$ final concentration) and filtered onto black polycarbonate filters (Osmonics, $0.22 \mu \mathrm{m}$ pore size, $25 \mathrm{~mm}$ diameter). Microscopic evaluation was carried out with a Zeiss Axiophot and a Zeiss Axioplan epifluorescence microscope at a magnification of $1600 \times$ and $320 \times$ for counting at least 1000 bacteria and 400 protists per sample, respectively. Ten to 20 images of single bacteria (corresponding to 500-700 cells), 50 
images of microcolonies in II-Och, and 10 images of Cryptomonas phaseolus, Ochromonas sp. and Cyclidium glaucoma were recorded with CCD cameras (Vosskühler VDS CCD-1300 and Cohu) mounted on the microscopes, and processed with the image analysis program LUCIA_D (http://www.lim.cz). At least 500 to 700 bacteria, 300 algae and 50 predators were measured. Area and perimeter of each cell were measured, and cell length and width and the mean cell volume (MCV) were calculated applying geometric approximation (Massana et al. 1997). Details on image processing and the use of macros can be found in Posch et al. (1997). Bacterial carbon content was calculated using the volume to carbon conversion factor published by Loferer-Krößbacher et al. (1998). Bacterial carbon was estimated to amount for $50 \%$ of bacterial dry weight. For the determination of protistan carbon, we applied the formula published by Menden-Deuer \& Lessard (2000). Total biomass was acquired by multiplying mean cellular carbon content with total abundance. Bacterial phosphorus content was calculated applying a conversion factor of $2 \mathrm{fg} \mathrm{P}$ cell $^{-1}$, while algal phosphorus content was assumed to be $900 \mathrm{fg} \mathrm{P}$ cell ${ }^{-1}$. These conversion factors have been determined for the same microbial community in earlier experiments (Mindl et al. 2005, this issue). For Ochromonas sp., a conversion factor of $303 \mathrm{fgP} \mathrm{cell}^{-1}$ was used (Rothhaupt 1996a), whereas no P conversion factor was available for C. glaucoma. Therefore, we calculated the ciliate's phosphorus content indirectly via subtraction of bacterial and algal $\mathrm{P}$ from the original phosphorus content of $50 \mu \mathrm{g} \mathrm{l}^{-1}$ of the medium. Running averages were calculated by averaging 3 consecutive sampling dates (6 d).

Counting and sizing was done in triplicates at 2 sampling occasions, with 3 parallel sampling bottles and 3 parallel preparations for all bacterial and protistan parameters. Statistical comparisons of parameters of cell morphology and biomass were performed by 1-way ANOVA.

Determination of bacterial assemblage composition. Five to $7 \mathrm{ml}$ of the fixed subsample (see above) were filtered onto white polycarbonate filters (Millipore, Type GTTP, $47 \mathrm{~mm}$ diameter, $0.2 \mu \mathrm{m}$ pore size), rinsed with distilled water, and stored at $-20^{\circ} \mathrm{C}$ until further processing. Sampling dates were selected for hybridization if significant changes were found either in bacterial or protistan abundance of II-Och or II-Cyc (altogether 7 timepoints).

Fluorescence in situ hybridization (FISH) was either carried out with fluorescently monolabeled oligonucleotide probes or with horseradish peroxidase labeled probes and catalyzed reporter deposition (CARD) (Pernthaler et al. 2002). No differences between detection rates by the 2 methods were found in the experimental assemblage (Sekar et al. 2003). CARD-FISH was performed with the probe HGC69a, targeted to the Actinobacteria (Sekar et al. 2003), with probes ALF-968 and BET-42a, specific for the $\alpha$ - and $\beta$-subclasses of Proteobacteria, respectively, and with probe EUB I-III, which detects most bacteria including Verrucomicrobia and Planctomycetes (Daims et al. 1999, Glöckner et al. 1999). Cell attachment and permeabilization on membrane filters and CARD-FISH was carried out as previously described with fluorescein-labeled tyramides for signal amplification (Pernthaler et al. 2002, Sekar et al. 2003). In addition, 3 specific probes labeled with the fluorescent dye $\mathrm{Cy} 3$ were applied for 3 microbial groups previously found in the experimental assemblage (Pernthaler et al. 2001). Probe CAU663 is targeted to bacteria affiliated with the Caulobacter spp.Brevundimonas spp. lineage ( $\alpha$-Proteobacteria) (probe sequence: 5'-GGA GTT CCA CAT ACC TCT-3') (Neef 1997). Probe BET3-446 is targeted to an 'Aquabacterium sp.' ( $\alpha$-Proteobacteria), and CF1-853, specific for bacteria from the Flavobacterium ferrugineum-Flexibacter sancti clade of the Sphingobacteriales (Pernthaler et al. 2001). FISH of filter sections was carried out as previously described (Alfreider et al. 1996, Glöckner et al. 1996), with the difference that cells had been pretreated as required for the CARD-FISH procedure (Sekar et al. 2003). The formamide concentrations in the hybridization buffers were $30 \%$ for probe CAU663, $40 \%$ for probe BET3446 , and $35 \%$ for probe CF1-853.

The filter sections were counter-stained with DAPI $\left(1 \mu \mathrm{g} \mathrm{ml}^{-1}\right)$ and inspected with a Zeiss Axiophot epifluorescence microscope at a magnification of $1250 \times$. At least 1000 DAPI-stained cells were counted per sample (500 cells for $\beta$-Proteobacteria, which were more frequent), corresponding to 15 to 500 hybridized cells. In the vessel II-Och, where besides single cells, microcolonies and aggregates also appeared, only single cells were analyzed by FISH. In addition, the food vacuoles of Cyclidium glaucoma and Ochromonas sp. were inspected for hybridized bacteria. For the mixotrophic flagellate this was only feasible using CARD-FISH because the chlorophyll autofluorescence masked the signals of the Cy3 monolabeled probes. To verify the precision of abundance determinations, 3 replicate hybridizations were made from different sampling dates with probes BET3-446 and BET42a. Ten images of bacteria were recorded with a CCD camera from each filter section. Composite pictures of cells from these images were arranged with the image analysis program LUCIA_D to visualize the succession of morphotypes of different bacterial clades with and without predators and the cell lengths of hybridized cells was measured. 


\section{RESULTS}

\section{Bacterial and protistan abundance (Fig. 1)}

In I-Stage and II-Con, similar patterns occurred in the course of the experiment. Initially the abundance of Cryptomonas phaseolus decreased slightly, remained stable until Day 35, and dropped to the lowest value at Day 51. Thereafter, algae recovered, with fluctuating abundances until the end of the experiment. Bacterial abundance showed the opposite trend, a slight initial increase to more or less stable cell numbers in the beginning, followed by a strong rise to a

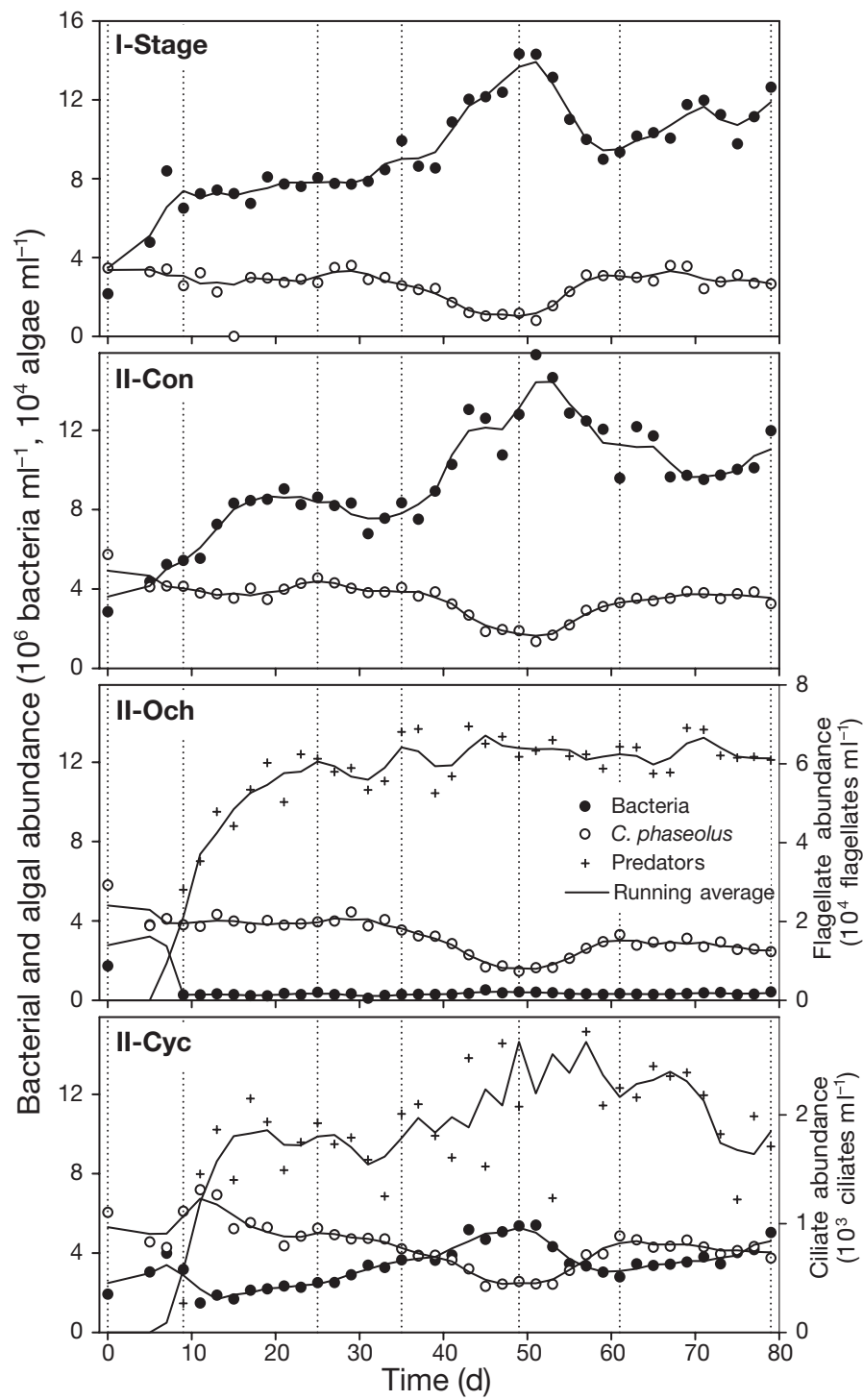

Fig. 1. Bacterial, algal and protistan abundances in the different vessels of the continuous cultivation system. Dotted lines indicate sampling dates selected for fluorescence in situ hybridization (FISH) analysis. Note the different units for bacterial and algal abundance on the left $y$-axis. Abbreviations as in Fig. 1 legend maximum at Day 51. Subsequently, bacterial abundance dropped, remained stable for some days and increased again at the end of the experiment. The ratio of bacterial versus algal biomass changed rapidly between Days 40 and 60, from 0.2 to 0.8 , and fluctuated between $<0.2$ and 0.4 thereafter (Fig. 2).

In II-Och, algae followed the same patterns as observed in I-Stage and II-Con. Ochromonas sp. grew exponentially until Day 19 and its numbers remained more or less stable thereafter (Fig. 1). Bacterial abundances decreased by more than 1 order of magnitude shortly after inoculation of the predator and remained at this low level (about $8 \%$ of the initial abundance) until the end of the experiment.

Algal numbers in II-Cyc showed the same trend as in the other variants, but formed higher abundances than in all other vessels and a short, but pronounced initial peak (Fig. 1). Cyclidium glaucoma increased exponentially at the beginning, but after a few days, the population densities started to drastically oscillate. These oscillations were most pronounced during the transient algae-bacteria imbalance situation between Days 40 to 60 (Fig. 2), when algal numbers were minimal. Bacterial abundance decreased after the introduction of the ciliate, but recovered slowly to higher than initial cell numbers at Day 51. The peak of bacterial abundances in the I-Stage between Days 40 to 60 was also reflected in II-Cyc.

\section{Bacterial and protistan biomass and phosphorus (Tables $1 \& 2$ )}

Bacteria in I-Stage had the smallest mean cell volume in comparison with all other variants. Therefore, bacte-

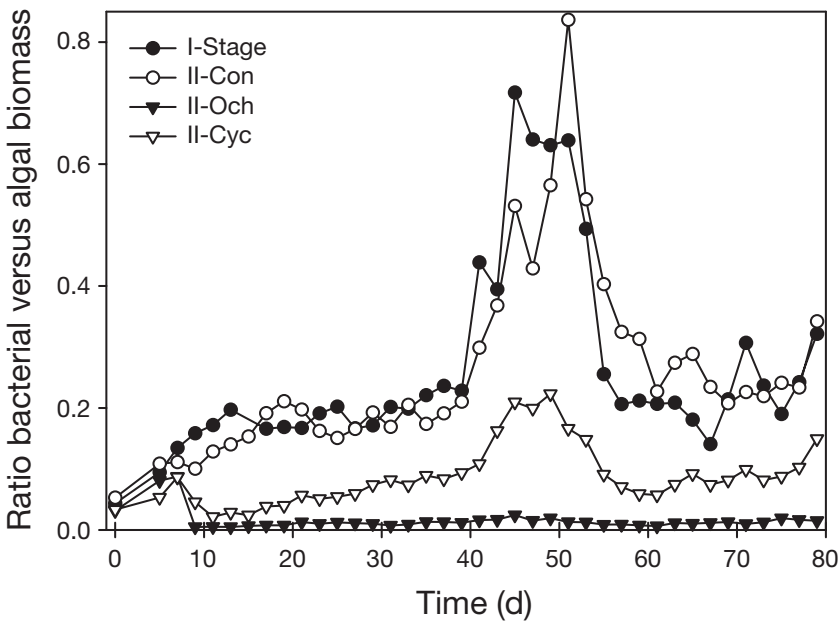

Fig. 2. Bacterial versus algal biomass ratio in the 4 vessels of the continuous cultivation system. I-Stage: Cryptomonas phaseolus and accompanying bacteria; II-Con: control; II-Och: Ochromonas sp.; II-Cyc: Cyclidium glaucoma 
Table 1. Community parameters of bacteria, algae and predators. Values are averages calculated after the introduction of the predators $(t=68 \mathrm{~d}, \mathrm{n}=35)$. Asterisks indicate a significant difference (1-way ANOVA, $\mathrm{p}<0.001)$ of the vessels II-Och and II-Cyc compared to vessel II-Con (control). Bac: bacteria; Alg: algae; Pre: predators (Ochromonas sp. in II-Och, Cyclidium glaucoma in II-Cyc); $\Sigma$ : sum of all parameters; ALF-968, CAU663, BET-42a, BET3-446, CF1-853, HGC-69a: fluorescence in situ hybridization (FISH) probes

\begin{tabular}{|c|c|c|c|c|c|c|c|}
\hline \multirow{2}{*}{$\begin{array}{l}\text { Community } \\
\text { parameter }\end{array}$} & & \multirow{2}{*}{ I-Stage } & \multirow{2}{*}{ II-Con } & \multirow{2}{*}{ Total } & \multirow{2}{*}{$\begin{array}{c}\text { II-Och }- \\
\text { Single cells }\end{array}$} & \multirow[b]{2}{*}{ Microcolonies } & \multirow{2}{*}{ II-Cyc } \\
\hline & & & & & & & \\
\hline \multirow{3}{*}{$\begin{array}{r}\text { Abundance } \\
(\text { cells ml-1) }\end{array}$} & $10^{6} \mathrm{Bac}$ & 9.90 & 10.00 & $0.44^{*}$ & $0.32^{*}$ & $0.12^{*}$ & $3.44^{*}$ \\
\hline & $10^{4} \mathrm{Alg}$ & 2.55 & 3.39 & $3.05^{*}$ & - & - & 4.25 \\
\hline & $10^{4}$ Pre & - & - & 5.97 & - & - & 0.20 \\
\hline \multirow{4}{*}{$\begin{array}{l}\text { Biovolume } \\
\left(\mathrm{mm}^{3} \mathrm{l}^{-1}\right)\end{array}$} & Bac & 1.153 & 1.882 & $0.081^{*}$ & $0.043^{*}$ & $0.038^{*}$ & $0.777^{*}$ \\
\hline & Alg & 9.53 & 14.15 & 13.45 & - & - & $17.51^{*}$ \\
\hline & Pre & - & - & 5.42 & - & - & 2.27 \\
\hline & $\Sigma$ & 10.69 & 16.03 & 18.96 & - & - & 20.56 \\
\hline \multirow{4}{*}{$\begin{array}{l}\text { Biomass } \\
\left(\mu \mathrm{C} \mathrm{C}^{-1}\right)\end{array}$} & Bac & 344 & 518 & $22^{*}$ & $12^{*}$ & $10^{*}$ & $208^{*}$ \\
\hline & Alg & 1432 & 2111 & 2000 & - & - & $2615^{*}$ \\
\hline & Pre & - & - & 886 & - & - & 318 \\
\hline & $\Sigma$ & 1776 & 2629 & 2908 & - & - & 3141 \\
\hline \multirow{4}{*}{$\begin{array}{l}\text { Phosphorus }{ }^{\mathrm{a}} \\
\left(\mu \mathrm{g} \mathrm{P}^{-1}\right)\end{array}$} & Bac & 19.8 & 20.1 & $0.9^{*}$ & $0.6^{*}$ & $0.2^{*}$ & $6.9^{*}$ \\
\hline & Alg & 23.0 & 30.5 & 27.4 & - & - & $38.3^{*}$ \\
\hline & Pre & - & - & 18.1 & - & - & 4.8 \\
\hline & $\Sigma$ & 42.8 & 50.6 & 46.4 & - & - & 50.0 \\
\hline \multirow{6}{*}{$\begin{array}{l}\text { Bacterial } \\
\text { assemblage } \\
\text { composition } \\
\text { (\% of DAPI) }\end{array}$} & ALF-968 & 5.6 & 7.6 & 13.2 & - & - & $27.3^{*}$ \\
\hline & CAU663 & 2.5 & 3.0 & $8.6^{*}$ & - & - & 4.4 \\
\hline & BET-42a & 86.5 & 81.9 & 43.9 & - & - & $44.8^{*}$ \\
\hline & ВET3-446 & 41.4 & 37.2 & $20.8^{*}$ & - & - & $19.2^{*}$ \\
\hline & CF1-853 & 2.9 & 4.6 & $19.1^{*}$ & - & - & 14.5 \\
\hline & HGC-69a & 0.5 & 0.7 & 1.6 & - & - & 0.8 \\
\hline
\end{tabular}

Table 2. Single-cell characteristics of bacteria, algae and predators. Values are averages calculated after the introduction of the predators $(t=68 \mathrm{~d}, \mathrm{n}=35)$. Asterisks indicate a significant difference in single-cell characteristics $(1$-way ANOVA, $\mathrm{p}<0.001)$ of the vessels II-Och and II-Cyc compared to vessel II-Con (control). Bac: bacteria; Alg: algae; Pre: predators (Ochromonas sp. in II-Och, Cyclidium glaucoma in II-Cyc); MCL: mean cell length; MCW: mean cell width; MCV: mean cell volume; CCC: cellular carbon content

\begin{tabular}{|c|c|c|c|c|c|c|c|}
\hline \multirow{2}{*}{$\begin{array}{l}\text { Cellular } \\
\text { parameter }\end{array}$} & & \multirow{2}{*}{ I-Stage } & \multirow{2}{*}{ II-Con } & \multirow[b]{2}{*}{ Total } & \multirow{2}{*}{$\begin{array}{l}\text { II-Och }- \\
\text { Single cells }\end{array}$} & \multirow[b]{2}{*}{ Microcolonies } & \multirow{2}{*}{ II-Cyc } \\
\hline & & & & & & & \\
\hline \multirow{3}{*}{$\begin{array}{l}\mathrm{MCL} \\
(\mu \mathrm{m})\end{array}$} & Bac & 1.47 & 1.83 & - & $1.43^{*}$ & $3.49^{*}$ & $1.46^{*}$ \\
\hline & Alg & 13.42 & 13.92 & 13.92 & - & - & 13.68 \\
\hline & Pre & - & - & 5.49 & - & - & 17.52 \\
\hline \multirow{3}{*}{$\begin{array}{r}\mathrm{MCW} \\
(\mu \mathrm{m})\end{array}$} & $\mathrm{Bac}$ & 0.34 & 0.39 & - & $0.37^{*}$ & $0.35^{*}$ & $0.47^{*}$ \\
\hline & Alg & 7.29 & 7.53 & 7.76 & - & - & 7.51 \\
\hline & Pre & - & - & 5.49 & - & - & 10.92 \\
\hline \multirow{3}{*}{$\begin{array}{l}\mathrm{MCV} \\
\left(\mu \mathrm{m}^{3}\right)\end{array}$} & $\mathrm{Bac}$ & 0.118 & 0.190 & - & $0.135^{*}$ & $0.322^{*}$ & $0.229^{*}$ \\
\hline & Alg & 381 & 422 & 448 & - & - & 413 \\
\hline & Pre & - & - & 90 & - & - & 1126 \\
\hline \multirow{3}{*}{$\begin{array}{l}\text { CCC } \\
\left(\text { fg C cell }{ }^{-1}\right)\end{array}$} & $\mathrm{Bac}$ & 34.9 & 51.6 & - & $38.0^{*}$ & $81.6^{*}$ & 60.3 \\
\hline & $10^{3} \mathrm{Alg}$ & 57.1 & 62.9 & 66.6 & - & - & 61.6 \\
\hline & $10^{3}$ Pre & - & - & 2.7 & - & - & 158.0 \\
\hline
\end{tabular}

rial biomass was about 1 third lower than in II-Con, although bacterial abundances in these 2 vessels were nearly equal. In II-Och, we distinguished between freely dispersed bacterial cells and microcolonies (Table 2). Single cells quickly became significantly shorter than in
II-Con, whereas cells in microcolonies were always significantly longer. Although the abundance of single cells was twice as high as of cells in microcolonies, total bacterial biomass of these 2 cell types was approximately equal. Bacterial widths were significantly larger in II-Cyc 
than in the control vessel (Table 2); the same holds true for bacterial cell volumes. Bacteria in this treatment had the highest cellular carbon content and formed relatively high biomasses. Algal phosphorus content of the second stage was highest in the vessel containing the ciliate (II$\mathrm{Cyc}$ ) and lowest in the vessel II-Och, where the flagellate might have incorporated phosphorus due to its mixotrophic life strategy.

\section{Changes of the bacterial assemblage due to grazing}

In II-Och, only a few freely dispersed cells were present. The remaining bacteria (up to $56 \%$ of total numbers) formed microcolonies with mean numbers of 5 to 7 cells per colony, large aggregates (containing more than 25 cells per aggregate) and long, single filaments. While microcolony forming cells could be counted easily due to their loose cell contact, this was not possible for densely packed aggregates. Therefore, only single cells were evaluated by FISH. Microcolonies also occurred in stage II-Cyc, but at a later timepoint, in lower densities and with other cell morphologies. The proportion of single cells was much higher in this vessel (II-Cyc).

FISH was performed for selected sampling dates that reflected drastic population changes of either bacteria or predators (see Fig. 1). The first 2 timepoints (Day 0 and Day 9) describe the situation before and shortly after inoculation of the 2 predators. The 3 subsequent timepoints (Days 25, 35 and 49) mirror the slight (IIOch) or pronounced (II-Cyc) recovery of bacterial abundances and the eventual peak of bacterial numbers in I-Stage and II-Con. During this period, predators reached very high abundances. The sixth datapoint describes the situation of bacterial abundance decrease while predators remained stable (Day 61). The last timepoint describes the community composition at the very end of the experiment, when bacterial numbers recovered in I-Stage, II-Con, and II-Cyc (Day 79).

Approximately $95 \%$ of DAPI-stained cells could be visualized at several timepoints in hybridizations with probe EUB I-III (data not shown). Slightly lower detection rates $(87 \%)$ were found in II-Och at the last sampling date. Nearly $100 \%$ of total bacterial abundance could be accounted for by the different probes (Fig. 3). At our level of analysis, the composition of the bacterial assemblages remained remarkably stable in I-Stage and II-Con even during large shifts in algal to bacterial biomass ratios. $\beta$-Proteobacteria formed the dominating group in these vessels (56 to $93 \%$ of DAPI-stained cells). About $50 \%$ of $\beta$-Proteobacteria could be assigned to 'Aquabacterium sp.' by probe BET3-446.

In II-Och, $\beta$-Proteobacteria decreased strongly, and constituted less than $30 \%$ of bacteria in this treatment

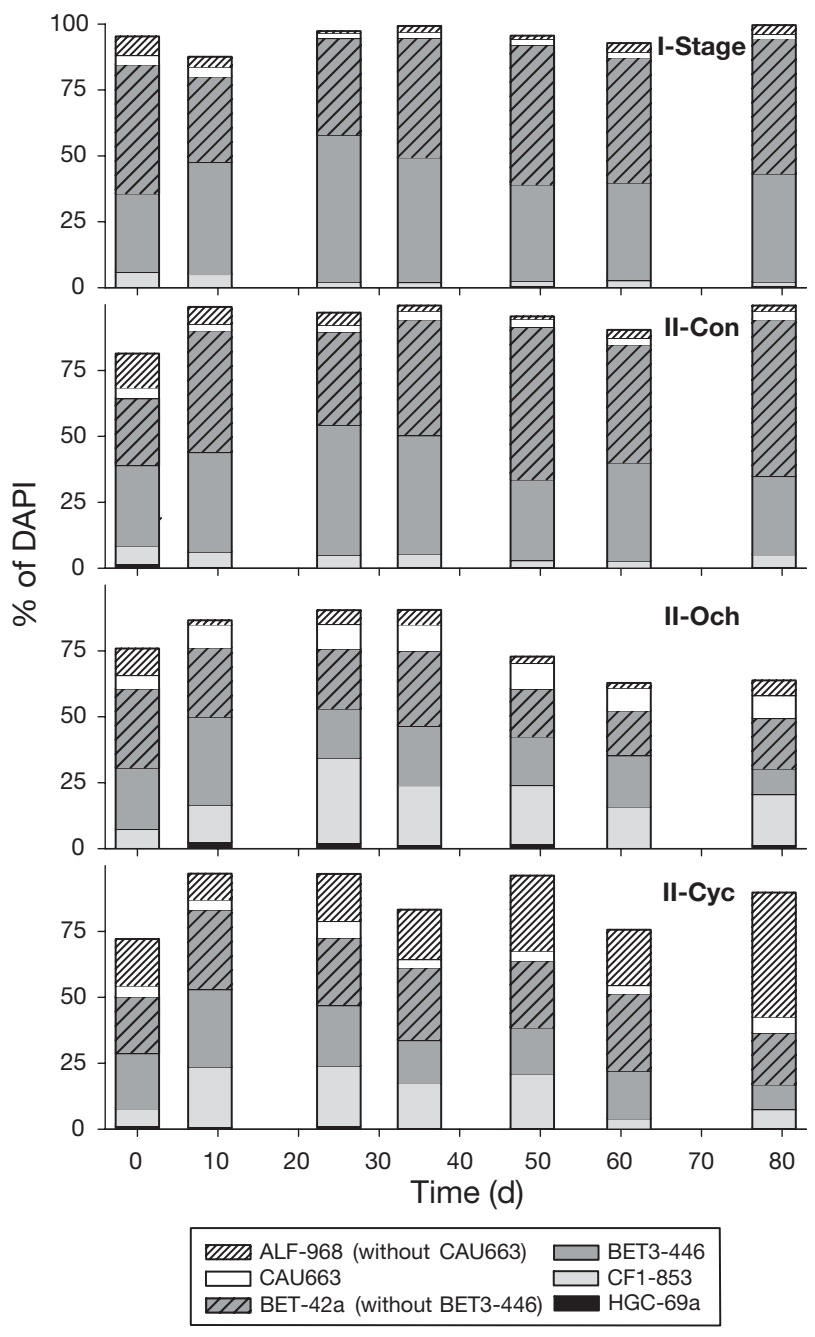

Fig. 3. Relative contribution of different bacterial groups to the assemblages, as determined by fluorescence in situ hybridization (FISH). Probes: ALF-968 ( $\alpha$-Proteobacteria without Caulobacter spp.), CAU663 (Caulobacter spp.), BET-42a ( $\beta$-Proteobacteria without 'Aquabacterium sp.'), BET3-446 ('Aquabacterium sp.'), CF1-853 (members of the Flexibacter sancti-Flavobacterium ferrugineum lineage), HGC-69a (Actinobacteria). Abbreviations as in Fig. 1 legend

at the end of the experiment (Figs. $3 \& 4$ ). Bacteria of the Flexibacter sancti-Flavobacterium ferrugineum lineage of Sphingobacteriales (Probe CF1-853) increased from $7 \%$ to a maximum of $32 \%$ of DAPIstained cells at Day 25 (Fig. 3). Both single cells and microcolonies with loose cell contact were detected with this probe, and were counted separately (Fig. 5). The abundance of single cells decreased slightly thereafter, whereas the abundance of cells in microcolonies remained high. Caulobacter-like bacteria hybridized by Probe CAU663 increased in proportion in II-Och (maximum, $10 \%$ at Day 35 ), whereas other $\alpha$-Proteobacteria decreased slightly. 
In II-Cyc we observed a strong relative decrease in the numbers of all $\beta$-Proteobacteria and of 'Aquabacterium sp.' (Fig. 3). Bacteria of the Flexibacter sancti-Flavobacterium ferrugineum lineage strongly increased until Day 49 (up to $21 \%$ ) (Fig. 5), but then dropped by almost 1 order of magnitude at Day 61. At the end of the experiment, a slight recovery was observed. Bacteria hybridized with probe CAU663 were rare and remained rather stable, but other $\alpha$ Proteobacteria strongly increased to $53 \%$ at the end of
A

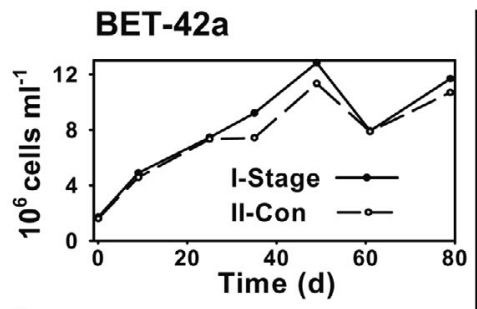

B

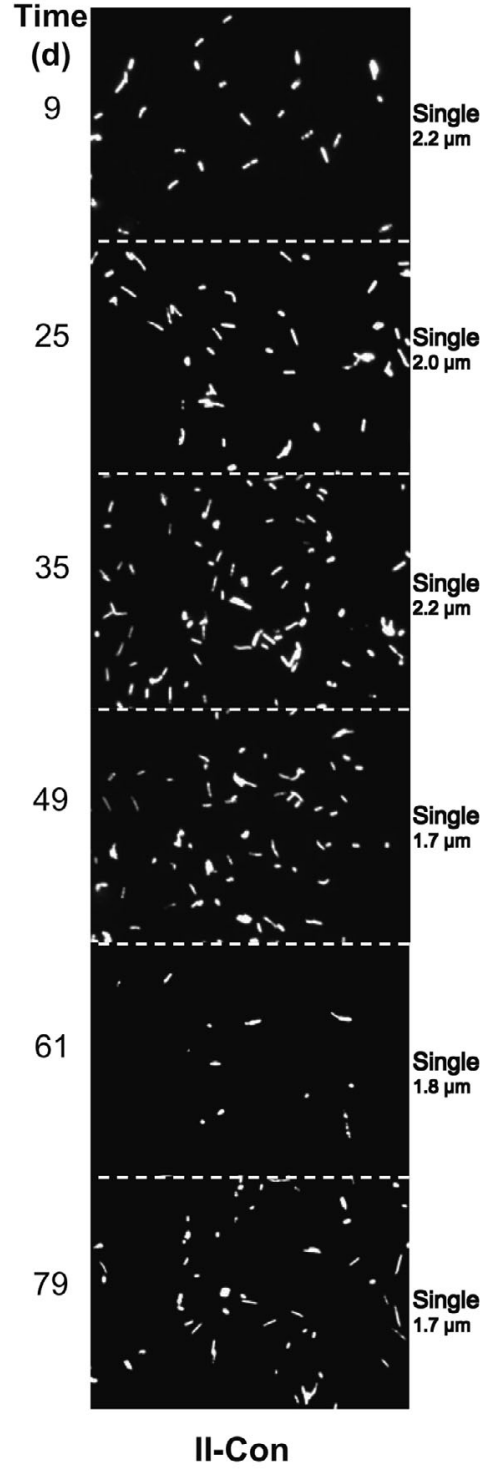

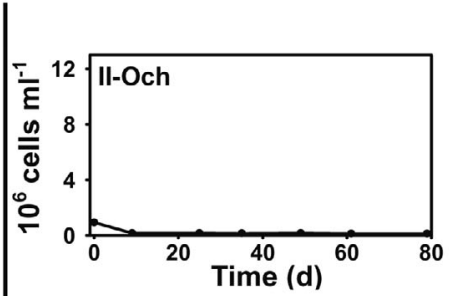
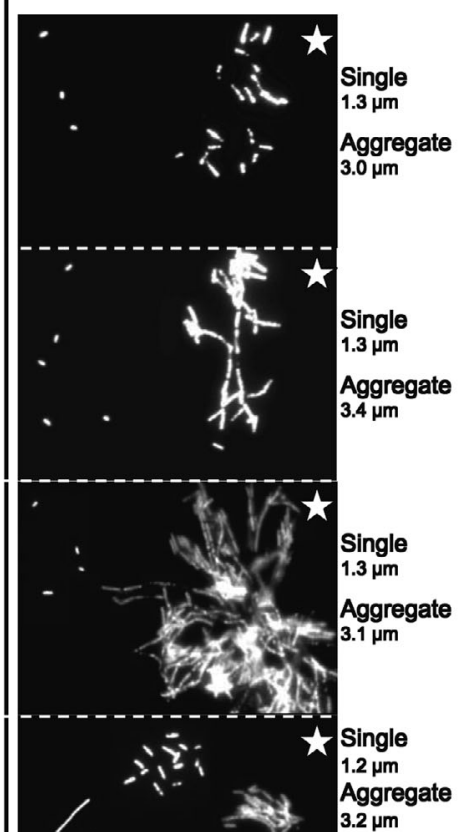

Single

$1.2 \mu \mathrm{m}$

Aggregate

$3.2 \mathrm{~mm}$

Filament

$9.2 \mu \mathrm{m}$

Microcolony

$1.4 \mu \mathrm{m}$

Single

$0.9 \mu \mathrm{m}$

Aggregate

$2.7 \mu \mathrm{m}$

Filament

5.7 um

Microcolony

$1.6 \mu \mathrm{m}$

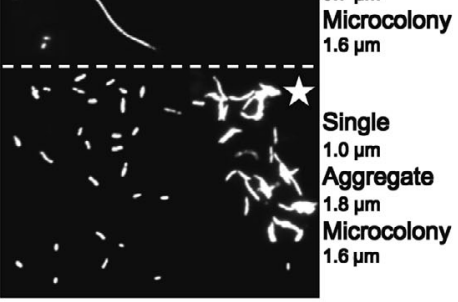

II-Och
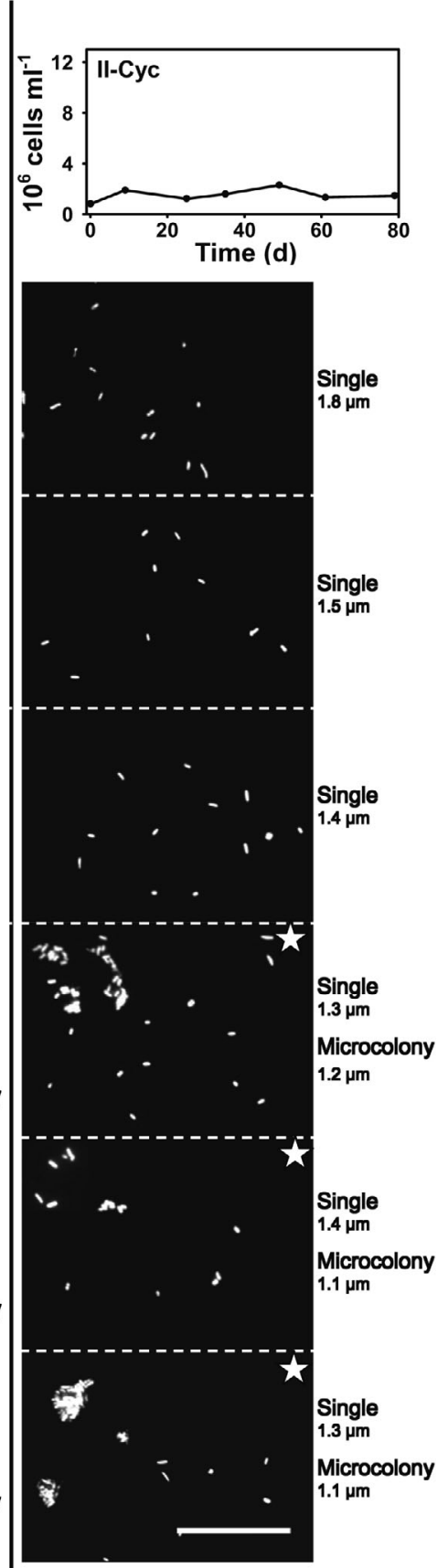

II-Cyc

Fig. 4. Succession in (A) abundance and (B) morphotype of bacterial populations detected by probe BET-42a in the vessels II-Con, II-Och and II-Cyc. On the right side of each picture in (B) is a short description of the cell types and the mean cell lengths. White stars in II-Och and II-Cyc indicate that pictures do not represent real abundances of bacteria, but are composed of different photographs in order to show diverse morphotypes. The scale bar at the bottom is $10 \mu \mathrm{m}$ and applies to all pictures. 
the experiment (Fig. 6). In this treatment, a succession of bacterial populations was observed that contrasted with the development of these populations in I-Stage and II-Con: a decline of $\beta$-Proteobacteria and a ra- pid increase of bacteria from the Flexibacter sanctiFlavobacterium ferrugineum lineage was followed by a strong decrease of the latter group and a bloom of $\alpha$ Proteobacteria.

A
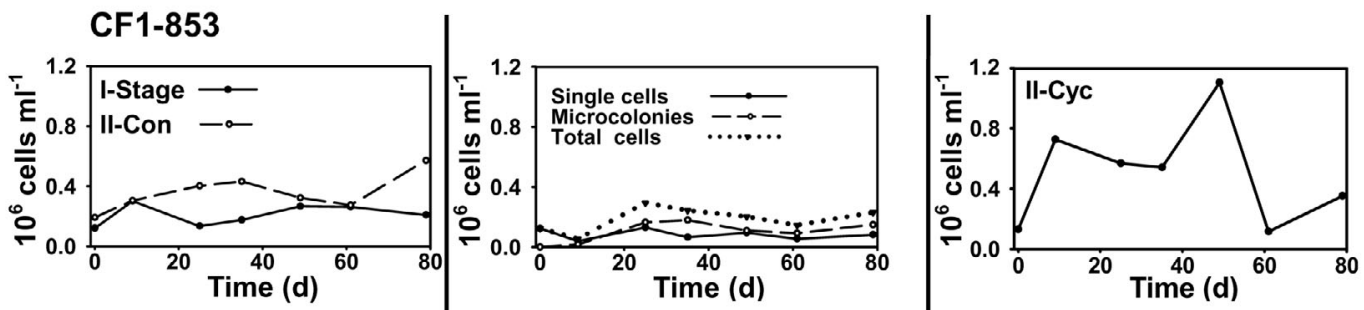

B
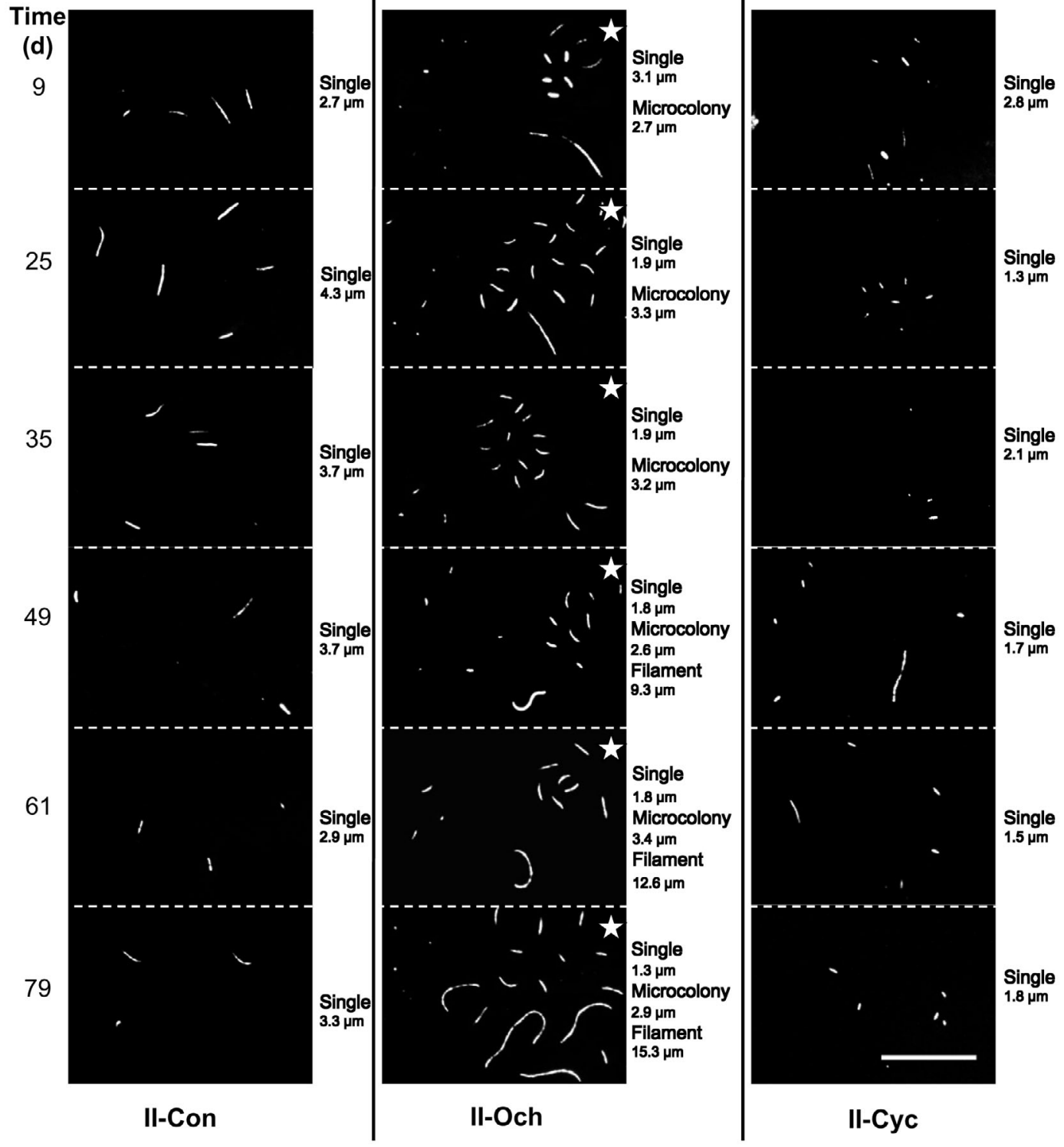

Fig. 5. Succession in (A) abundance and (B) morphotype of the bacterial populations detected by probe CF1-853 in the vessels II-Con, II-Och and II-Cyc. On the right side of each picture in (B) is a short description of the cell types and the mean cell lengths. White stars in II-Och indicate that pictures do not represent real abundances of bacteria but are composed of different photographs in order to show diverse morphotypes. The scale bar at the bottom is $10 \mu \mathrm{m}$ and applies to all pictures. Abbreviations as in Fig. 1 legend 
Morphological shift of the different bacterial groups

$\beta$-Proteobacteria (Fig. 4) showed a high phenotypic plasticity, and 5 different morphotypes could be observed. In I-Stage and II-Con, these bacteria formed medium-sized single rods, whereas in II-Och, all single cells were smaller. Immediately after inoculation of Ochromonas sp., large aggregates occurred, which
A

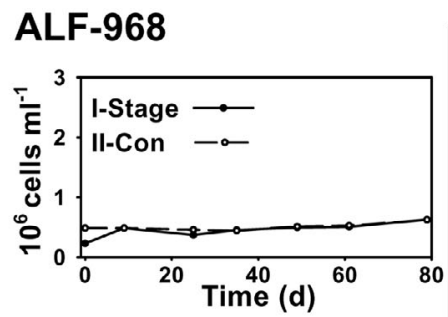

B

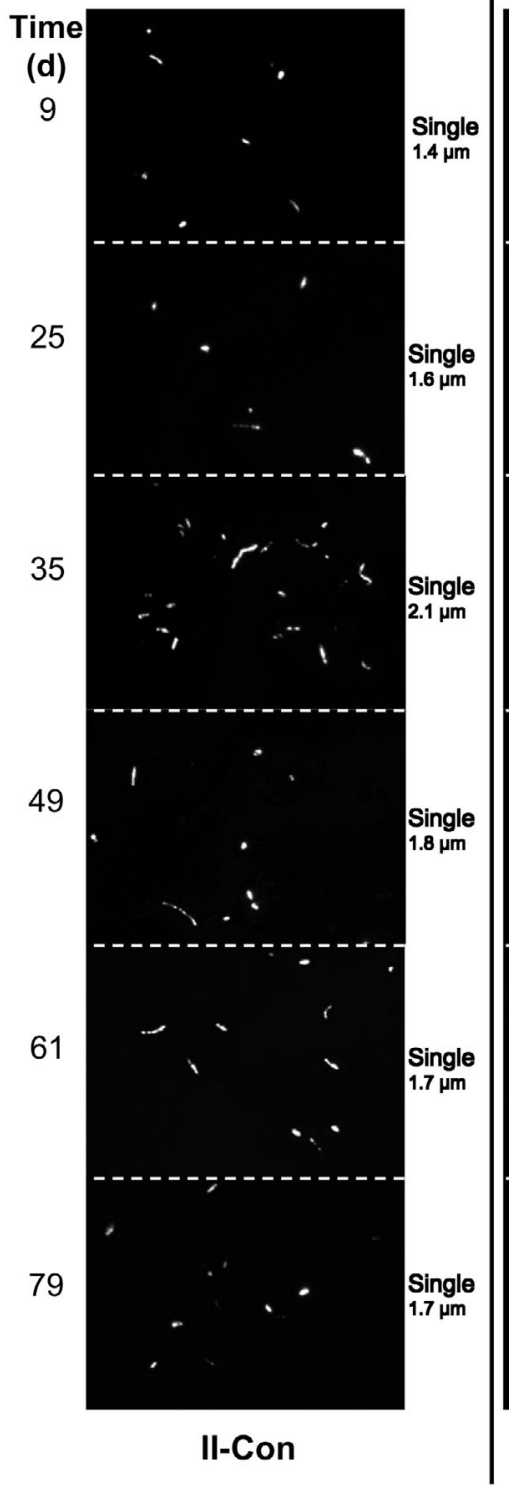

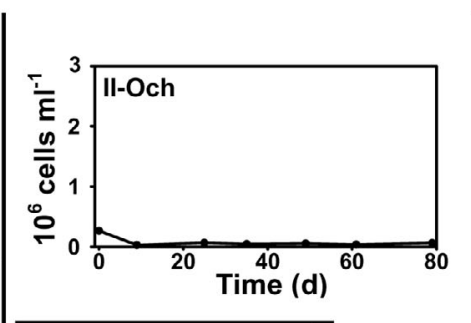
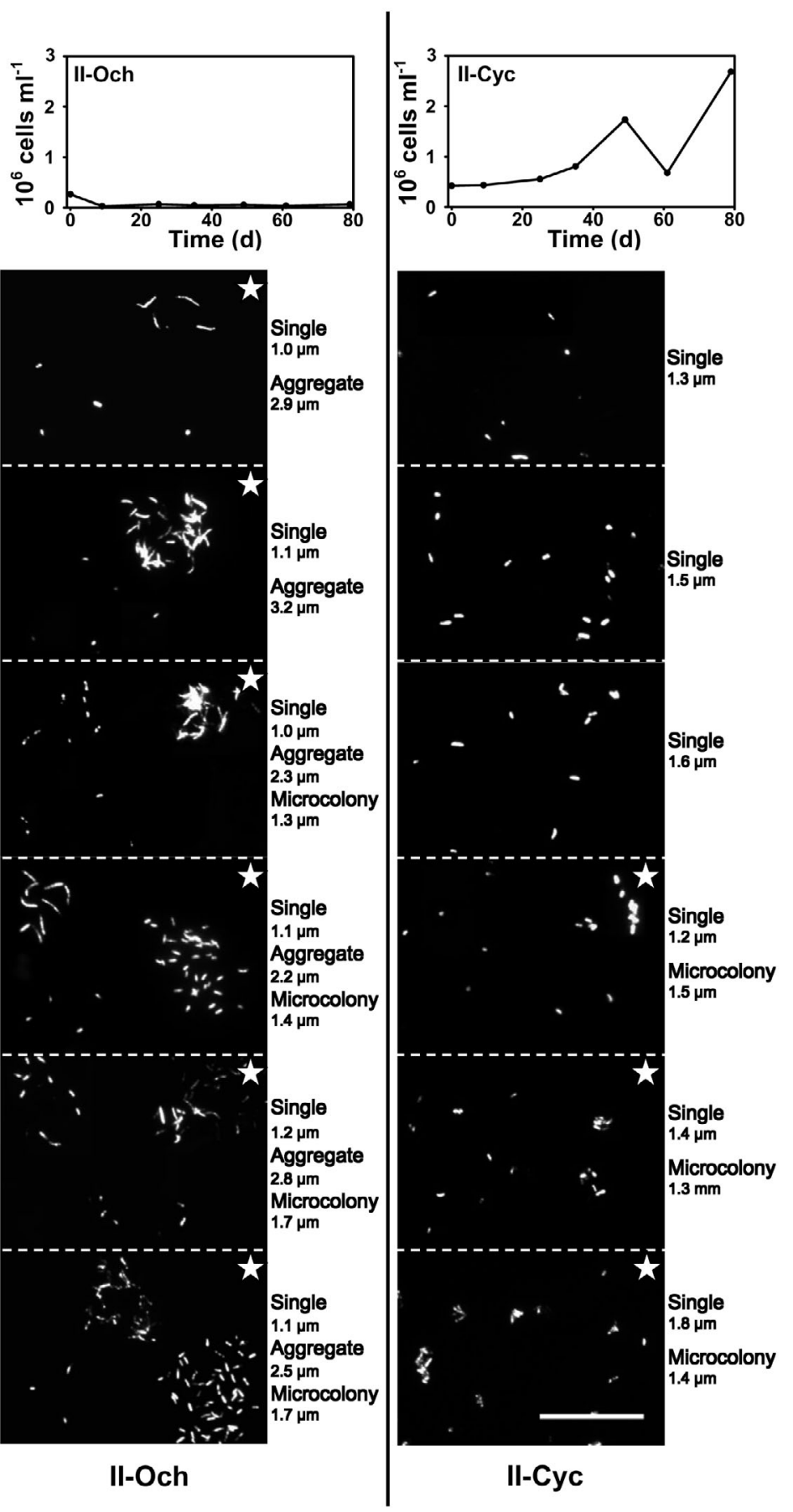

Fig. 6. Succession in (A) abundance and (B) morphotype of the bacterial populations detected by probe ALF-968 in the vessels II-Con, II-Och and II-Cyc. On the right side of each picture in (B) is a short description of the cell types and the mean cell lengths. White stars in II-Och and II-Cyc indicate that pictures do not represent real abundances of bacteria but are composed of different photographs in order to show diverse morphotypes. The scale bar at the bottom is $10 \mu \mathrm{m}$ and applies to all pictures. 
contained primarily bacteria related to Aquabacterium sp. (probe BET3-446), with some cells affiliating with Caulobacter spp. (probe CAU663). These aggregates were not very abundant, but became very large (more than 25 cells per aggregate). At Day 49, 2 more morphotypes of $\beta$-Proteobacteria were discernable: long rare filaments and small microcolonies with loose cell contact, which increased in numbers until the end of the experiment. These 2 morphotypes could not be detected with probe BET3-446. All $\beta$-Proteobacteria in II-Cyc formed rod-shaped single cells until Day 49. Afterwards, microcolonies with tight cell contact appeared, which became very abundant. Cells in these colonies could not be detected with probe BET3-446.

Bacteria related to the Flexibacter sancti-Flavobacterium ferrugineum lineage (Fig. 5) formed single rods in I-Stage and II-Con. In II-Och, there was a morphological separation between small single cells and microcolonies containing 5 to 7 larger cells with loose cell contact. These colonies became dominant during the experiment (up to $53 \%$ in comparison to abundances of single cells). At Day 49, a third cell type hybridizing with CF1-853 appeared, consisting of long filaments, which slightly increased in abundance until the end of the experiment. In the ciliate vessel (II-Cyc), only 1 cell type was hybridized by probe CF1-853, i.e. small rod-shaped single cells.

$\alpha$-Proteobacteria (Fig. 6) fell into a large range of size classes in I-Stage and II-Con, from small coccoid forms to rod-shaped bacteria. In II-Och, shortly after inoculation of Ochromonas sp., Caulobacter spp. was present in aggregates dominated by 'Aquabacterium sp.' (see above). The remaining $\alpha$-Proteobacteria formed very small single cells until Day 35. At this timepoint small colonies of $\alpha$-Proteobacteria with loose cell contact appeared, which became more abundant towards the end of the experiment. In the vessel containing Cyclidium glaucoma, $\alpha$-Proteobacteria formed rod-shaped single cells. At Day 49, small colonies appeared also in II-Cyc, but these colonies had direct cell contact, and were not hybridized by probe CAU663.

\section{DISCUSSION}

\section{Effects of predators with differing feeding strategies}

Ochromonas sp. reached very high abundances shortly after inoculation and minimized bacterial abundance dramatically (Fig. 1). In contrast to former studies on the same experimental community no bloom of Actinobacteria was observed in II-Och (Pernthaler et al. 2001, T. Posch et al. unpubl. data). However, we still found a clear relationship between grazing pressure and bacterial size structure. Shortly after intro- duction of the predator, the bacterial assemblage responded by a bidirectional shift towards small single cells and very large and complex morphologies, such as aggregates, microcolonies and filaments. This grazing-protective strategy has also been found in previous studies (Güde et al. 1989, Pernthaler et al. 1996, Hahn \& Höfle 1999, Jürgens \& Matz 2002). Ochromonas sp. preferentially feeds on bacteria larger than $0.2 \mu \mathrm{m}^{3}$ $(\sim 0.7 \mu \mathrm{m}$ in diameter, Andersson et al. 1986). Although there was a shift towards smaller cells, $78 \%$ of all freeliving bacterial cells found in II-Och were within the edible size range $\left(>0.2 \mu \mathrm{m}^{3}\right)$, which probably explains why these cells did not recover in abundance. On the one hand, morphological changes could be a consequence of size selectivity by the flagellate. On the other hand, the observed phenomena could also be caused by the extremely high total grazing rates irrespective of size selectivity. Due to its mixotrophic life strategy, Ochromonas sp. can maintain high densities, thus exerting high grazing pressure on bacteria even when only little particulate food is available. When grown under light, the flagellate increasingly uses its ability to grow photosynthetically, if bacterial densities fall below a concentration of $<10^{6}$ cells ml ${ }^{-1}$ (Rothhaupt 1996b, 1997), and it has to take up phosphate. As a consequence, bacteria in II-Och had to compete for phosphorus not only with the algae (Mindl et al. 2005), but also with a predominantly phototrophic bacterivore. Another effect of the phosphorus-incorporation of the flagellate is that algae had the lowest phosphorus content in this vessel.

In contrast, exclusively heterotrophic protists such as Cyclidium glaucoma release surplus phosphorus and other nutrients, and therefore stimulate P-limited algal and bacterial growth (Eccleston-Parry \& Leadbeater 1995, Rothhaupt 1997). This beneficial effect was found in II-Cyc, where algae reached higher densities than in all other vessels. Interestingly, bacteria grazed by the filter feeder C. glaucoma reacted with an increase in cell width rather than in cell length (Table 2). This phenomenon was also observed in earlier chemostat experiments (Posch et al. 2001). Considering the complex structures of the ciliate feeding apparatus, it is conceivable that such increased cell width might provide at least partial protection against grazing by C. glaucoma.

\section{Effects on assemblage composition (Table 3)}

The ability to form grazing-resistant morphologies seems to be widespread among various bacterial phylotypes (Table 3). Field studies as well as laboratory experiments typically show that freshwater $\beta$-Proteobacteria are negatively affected by protistan grazing if 
Table 3. Examples for the effects of protistan grazing on the bacterial assemblage composition observed in (a) field and (b) chemostat studies applying fluorescence in situ hybridization (FISH) (only examples for freshwater systems). Abbreviations for oligonucleotide probes: Bacteria: EUB = EUB338; Actinobacteria: Ac1 = Ac1-847, HGC = HGC-69a; Archaea: ARCH = ARCH915; $\alpha$-Proteobacteria: ALF = ALF-968, CAU = CAU663, PS = Pseudomonas sp.; $\beta$-Proteobacteria: BET = BET-42a, BONE = BONE23a; BET3 = BET3-446, R-BT = R-BT65; $\gamma$-Proteobacteria: GAM = GAM-42a; Cytophaga-Flavobacterium-Bacteroides: CF $=$ CF-319a, CF1 $=$ CF1-853, R-FL $=$ R-FL615. FRACT $=$ size fractionation, LONG = longitudinal transect, TRANS = transplant experiment

\begin{tabular}{|c|c|c|c|c|c|c|}
\hline $\begin{array}{l}\text { (a) } \\
\text { Lake }\end{array}$ & $\begin{array}{l}\text { Applied } \\
\text { probes }\end{array}$ & $\begin{array}{l}\text { EUB } \\
(\%)\end{array}$ & $\begin{array}{l}\text { Natural } \\
\text { assemblages }\end{array}$ & Effects of grazing & $\begin{array}{l}\text { Time/ } \\
\text { Notes }\end{array}$ & Source \\
\hline $\begin{array}{l}\text { Small } \\
\text { fishless pond }\end{array}$ & $\begin{array}{l}\text { EUB } \\
\text { HGC } \\
\text { ALF1b } \\
\text { BET BONE } \\
\text { GAM } \\
\text { CF }\end{array}$ & $60-85$ & $\mathrm{BET}>\mathrm{CF}$ & $\begin{array}{l}\text { Decrease in BET \& CF } \\
\text { Increase in ALF \& GAM } \\
\text { Mainly ALF formed filaments }\end{array}$ & $\begin{array}{l}0-140 \mathrm{~h} \\
\text { Data from } \\
\text { Daphnia-free } \\
\text { variants }\end{array}$ & (1) \\
\hline $\begin{array}{l}\text { Rímov } \\
\text { reservoir }\end{array}$ & $\begin{array}{l}\text { EUB } \\
\text { ALF } \\
\text { BET } \\
\text { GAM } \\
\text { CF }\end{array}$ & $45-60$ & $\begin{array}{l}\mathrm{BET} \sim \mathrm{CF}>\mathrm{ALF}>\mathrm{GAM} \\
\mathrm{BET}>\mathrm{CF}>\mathrm{ALF}>\mathrm{GAM}\end{array}$ & $\begin{array}{l}\text { Increase in ALF \& CF } \\
\text { ALF formed filaments } \\
\text { Decrease in BET } \\
\text { increase in ALF \& CF } \\
\text { CF formed filaments }\end{array}$ & $\begin{array}{l}0-96 \mathrm{~h} \\
\text { FRACT, clear } \\
\text { water phase } \\
0-96 \mathrm{~h} \\
\text { FRACT, late } \\
\text { phytoplankton } \\
\text { peak }\end{array}$ & $\begin{array}{l}(2) \\
(2) \\
\end{array}$ \\
\hline $\begin{array}{l}\text { Three small } \\
\text { fishless ponds }\end{array}$ & $\begin{array}{l}\text { EUB } \\
\text { ARCH } \\
\text { ALF1b }\end{array}$ & & & $\begin{array}{l}\text { Aggregates dominated by } \\
\text { ALF, freely dispersed } \\
\text { cells dominated by BET }\end{array}$ & $\begin{array}{l}\text { Data from } \\
\text { Daphnia-free } \\
\text { variants }\end{array}$ & (3) \\
\hline Rixdorf & $\begin{array}{l}\text { BET } \\
\text { GAM } \\
\text { CF }\end{array}$ & $70-95$ & $\mathrm{BET} \sim \mathrm{CF}$ & $\begin{array}{l}\text { Increase in BET \& ALF } \\
\text { Decrease in } \mathrm{CF}\end{array}$ & $0-94 \mathrm{~h}$ & \\
\hline Freudenholm & & $60-80$ & $\mathrm{BET}>\mathrm{CF}>\mathrm{ALF}$ & $\begin{array}{l}\text { Increase in BET \& } \mathrm{ARCH} \\
\text { Decrease in } \mathrm{CF}\end{array}$ & $0-116 \mathrm{~h}$ & \\
\hline Hasselburg & & $50-80$ & $\mathrm{BET}>\mathrm{CF}>\mathrm{ALF} \sim \mathrm{ARCH}$ & Increase in ALF & $0-94 \mathrm{~h}$ & \\
\hline Sau Reservoir & $\begin{array}{l}\text { EUB } \\
\text { ALF } \\
\text { BET } \\
\text { GAM } \\
\text { CF }\end{array}$ & $60-90$ & $\begin{array}{l}\mathrm{CF}>\mathrm{BET}>\mathrm{ALF} \sim \mathrm{GAM} \\
\text { Biomass dominance } \\
\text { of BET }\end{array}$ & Decrease in BET \& CF & $\begin{array}{l}\text { April, July } \\
1997 \\
\text { LONG }\end{array}$ & (4) \\
\hline $\begin{array}{l}\text { Rímov } \\
\text { reservoir }\end{array}$ & $\begin{array}{l}\text { EUB } \\
\text { ALF } \\
\text { BET } \\
\text { R-BT } \\
\text { GAM } \\
\text { CF } \\
\text { R-FL }\end{array}$ & $75-85$ & $\mathrm{BET}>\mathrm{CF}>\mathrm{GAM}>\mathrm{ALF}$ & $\begin{array}{l}\text { Increase in BET \& CF } \\
\text { R-FL formed filaments } \\
\text { Aggregates by BET \& CF }\end{array}$ & $\begin{array}{l}0-96 \mathrm{~h} \\
\text { FRACT }\end{array}$ & (5) \\
\hline $\begin{array}{l}\text { Rímov } \\
\text { reservoir }\end{array}$ & $\begin{array}{l}\text { EUB } \\
\text { ALF } \\
\text { BET } \\
\text { R-BT } \\
\text { GAM } \\
\text { CF } \\
\text { R-FL }\end{array}$ & $50-85$ & $\mathrm{BET} \sim \mathrm{CF}>\mathrm{R}-\mathrm{BT}>\mathrm{GAM}$ & Decrease in BET \& R-BT & $\begin{array}{l}0-96 \mathrm{~h} \\
\text { FRACT } \\
\text { TRANS }\end{array}$ & (6) \\
\hline
\end{tabular}

they morphologically resemble cocci or small single rods (Jürgens et al. 1999, Posch et al. 2001, Šimek et al. 2001b, Gasol et al. 2002). Via food vacuole inspection, we found that $85 \%$ of all ciliates and $23 \%$ of all flagellates had ingested $\beta$-Proteobacteria. This hints at an unresolved paradox within aquatic microbial communities, since this phylogentic group (together with Acti- nobacteria) forms a prominent fraction in many freshwater systems (Methé \& Zehr 1999, Glöckner et al. 2000, Burkert et al. 2003). However, at present only few groups of the $\beta$-Proteobacteria are known to be strongly affected by grazing, e.g. 'Aquabacterium sp.' (Pernthaler et al. 2001) and members of the freshwater beta I clade (Šimek et al. 2001b). 
Table 3 (continued)

\begin{tabular}{|c|c|c|c|c|c|c|}
\hline $\begin{array}{l}\text { (b) } \\
\text { Chemostat } \\
\text { predators }\end{array}$ & $\begin{array}{l}\text { Applied } \\
\text { probes }\end{array}$ & $\begin{array}{c}\text { EUB } \\
(\%)\end{array}$ & $\begin{array}{l}\text { Natural } \\
\text { assemblages }\end{array}$ & Effects of grazing & $\begin{array}{l}\text { Time/ } \\
\text { Notes }\end{array}$ & Source \\
\hline Bodo saltans & $\begin{array}{l}\text { EUB } \\
\text { ALF } \\
\text { BET } \\
\text { GAM } \\
\text { CF }\end{array}$ & $80-97$ & $\mathrm{BET}>\mathrm{ALF} \sim \mathrm{GAM}>\mathrm{CF}$ & $\begin{array}{l}\text { Decrease in BET } \\
\text { Increase in ALF }\end{array}$ & $12 \mathrm{~d}$ & (7) \\
\hline Ochromonas sp. & $\begin{array}{l}\text { EUB } \\
\text { PS } \\
\text { BET } \\
\text { GAM }\end{array}$ & 81 & GAM $>$ BET $>$ PS & Increase in flocs (PS) & $261 \mathrm{~d}$ & (8) \\
\hline $\begin{array}{l}\text { Cyclidium glaucoma, } \\
\text { Bodo saltans, } \\
\text { Ochromonas sp. }\end{array}$ & $\begin{array}{l}\text { Ac1 } \\
\text { CAU } \\
\text { BET3 }\end{array}$ & - & $\mathrm{BET} 3 \sim \mathrm{CF}>\mathrm{CAU}>\mathrm{Ac} 1$ & $\begin{array}{l}\text { Dominance of Ac1 } \\
\text { Increase in ALF \& CF1 } \\
\text { Decrease in BET3 }\end{array}$ & $12-16 \mathrm{~d}$ & (9) \\
\hline Cyclidium glaucoma & $\begin{array}{l}\text { ALF } \\
\text { BET } \\
\text { CF }\end{array}$ & - & $\mathrm{ALF}>\mathrm{BET}>\mathrm{CF}$ & Decrease in BET \& CF & $16 \mathrm{~d}$ & $(10)$ \\
\hline
\end{tabular}

Some pelagic freshwater $\beta$-Proteobacteria might be able to rapidly increase their growth rates upon environmental change (Jürgens et al. 1999, Šimek et al. $2001 \mathrm{~b}$, Burkert et al. 2003). Other species of $\beta$-Proteobacteria potentially exhibit high phenotypic plasticity, i.e. they can form various morphotypes such as microcolonies, filaments and aggregates (Jürgens et al. 1999, Šimek et al. 2001b, Hahn et al. 2004). In our system, such large and complex structures were obviously resistant to protistan grazing, as they were not found in protists food vacuoles and maintained relatively high abundances. $\beta$-Proteobacteria related to the drinkingwater biofilm bacterium Aquabacterium sp. (Kalmbach et al. 1999) were able to form morphotypes that were resistant even to strong grazing (Fig. 4). They constituted $46 \pm 8 \%$ of all $\beta$-Proteobacteria in I-Stage, II-Con and II-Cyc, and this proportion remained stable throughout the experiment with slightly lower values for II-Och $(42 \pm 7 \%)$. These bacteria formed large branched colonies consisting of at least 25 cells in the vessel containing the flagellate. They are phylogenetically closely related to stream biofilm bacteria (Brümmer et al. 2003), and to a freshwater isolate (MWH55) that was found to develop microcolonies when exposed to grazing by Ochromonas sp. strain DS (Hahn et al. 2004). In our experiment, this extreme response to grazing pressure was only observed in II-Och but not in II-Cyc, where grazing rates were much lower. At present, we can only speculate if this phenomenon is linked to the contrasting size selectivity of the 2 preda- tors, or if it is due to different remineralization rates of the mixotrophic and the heterotrophic protist.

Members of the $\alpha$-Proteobacteria usually do not form a dominant fraction of freshwater bacterioplankton (Methé \& Zahr 1999, Glöckner et al. 2000, Klammer et al. 2002). Interestingly, these bacteria were favored in many investigations that feature an experimental increase in grazing pressure (Table 3, Jürgens et al. 1999, Šimek et al. 1999). Bacteria hybridized by probe CAU663 contributed $48 \pm 18 \%$ of all $\alpha$-Proteobacteria in I-Stage and II-Con, with higher values for II-Och $(68 \pm 18 \%)$ and lower values for II-Cyc (18 $\pm 7 \%$ ). The typical long stalks of single Caulobacter spp. cells (Poindexter et al. 2000) might have caused difficulties especially for the filter-feeding ciliate which only rarely ingested bacteria detected by probe CAU663. Members of $\alpha$-Proteobacteria seemed to be generally less vulnerable to grazing by Cyclidium glaucoma, although they were also found in the ciliate's food vacuoles. However, a variety of morphotypes related to $\alpha$-Proteobacteria dominated the bacterial assemblage in II-Cyc at the end of the experiment. Again, it seems to be a paradox that members of $\alpha$-Proteobacteria can coexist with strong grazing pressure but are rare in freshwaters. This suggests that factors other than protistan grazing also substantially affect the abundance of particular bacterial genotypes in freshwater systems.

Apart from morphological changes of single taxonomic groups we could also observe bacterial coexis- 
tence in aggregates as a result of strong grazing pressure. The large branched colonies formed by members of the BET3-446 cluster were always associated with single cells affiliated with Caulobacter spp. A similar phenomenon has been described from samples of a meso-eutrophic reservoir, where large aggregates of $\beta$-Proteobacteria were interspersed with members of the Sphingobacteriales (Šimek et al. 2001b). Thus, protistan grazing does not only directly affect individual phylogentic clusters, but may also modify the interactions between different taxonomic groups.

Bacteria of the Flexibacter sancti-Flavobacterium ferrugineum lineage of Sphingobacteriales also exhibited a wide spectrum of morphotypes. Interestingly, microcolonies and long filaments only occurred in the presence of Ochromonas sp., but not with Cyclidium glaucoma (Fig. 5). This again illustrates that microbial predation-defence mechanisms may be triggered only by particular predator species. Since the probe is targeted to a lineage harbouring a number of distinct phylotypes (Pernthaler et al. 2001), the presence of both filaments and microcolonies may either reflect the phenotypic plasticity of a single population, or of cooccurring bacterial populations affiliated with this phylogenetic clade.

\section{Successions in mixed microbial assemblages}

It is likely that microbial assemblages respond differently to gradual and to rapid changes of grazinginduced mortality. In most experimental studies, 'unnaturally' strong shifts of grazing pressure are induced, either by inoculating high numbers of protistan predators or by decoupling the microbial food web by size fractionations (Table 3). Such experimental set-ups will lead to rather extreme responses, which probably occur in nature only during particular time periods. In contrast, it is not well understood how a mixed bacterial assemblage is affected by varying levels of protistan grazing pressure, e.g. throughout the season. Freshwater pelagic bacteria are typically confronted with changing intensities of grazing pressure, as well as with shifts in the species composition of the dominant bacterivorous protists (Sanders et al. 1989, Sommaruga \& Psenner 1995, Cleven \& Weisse 2001). Therefore, it is likely that seasonal community patterns of bacterivorous protists are reflected in successions of bacterial phylotypes. In addition, these successions will also be determined by bottom-up factors, e.g. the availability of limiting substrates and nutrients.

Unfortunately, it is hardly feasible to experimentally mimic protistan species successions. However, it is possible to examine if there might be successions of mixed bacterial assemblages if exposed to different grazing modes over an extended period of time. In our experiment, we attempted to model a microbial community which features some of the complexity of natural planktonic systems, where interactions between bacteria, algae, and bacterivorous protists occur simultaneously. We hypothesized that there might be no stable long-term response of the bacterial assemblage in such a complex system even if the physico-chemical parameters were tightly controlled. This was verified both by the more pronounced genotypic shifts in the grazing exposed assemblages (Fig. 3), and the successions of different grazing resistant morphotypes (Figs. 4 to 6).

Another very basic interaction that may introduce instability both in our system and in the freshwater pelagic zone is the competition for limiting phosphorus. The repeatedly observed oscillation of bacterial versus algal biomass ratios in the cultivation system (Fig. 2, Mindl et al. 2005) is most likely caused by this phenomenon. According to the so-called phytoplankton-bacteria paradox (Bratbak \& Thingstad 1985), the ratio of bacterial versus algal biomass increases with decreasing availability of phosphorus. In previous chemostat experiments with media containing $>40 \mu \mathrm{g} \mathrm{P}^{-1} \mathrm{~d}^{-1}$ (Mindl et al. 2005), the ratio of bacterial versus algal biomass ranged around 0.05 to 0.1 . These ratios remained stable over periods of 2 mo. In contrast, the use of media with $20 \mu \mathrm{g} \mathrm{P} \mathrm{l}^{-1} \mathrm{~d}^{-1}$ led to a bacteria:algae ratio of 0.2 to 0.3 , followed by considerable oscillations (Fig. 2 and Mindl et al. 2005). A similar situation may occur in natural oligo- to mesotrophic freshwater systems. Since bacterial carbon supply in the first stage of our system exclusively depends on exudates of Cryptomonas phaseolus, these imbalance situations only lasted for several days.

\section{Implications for future studies}

Presently it is still poorly understood which bacterial phylotypes in freshwaters are preferentially eliminated by bacterivores, and how the development of different grazing protection mechanisms by specific bacterial populations is affected by the availability of nutrients. Future studies are required to explore how (1) the intensity of grazing, (2) the community composition and (3) the size selectivity of protistan grazers will influence the phenotypes and the seasonal dynamics of different bacterial populations in pelagic systems.

Acknowledgements. This study was supported by the Austrian Science Fund (Project FWF P14637-Bio and Project FWF P17554-B06) and by the Max Planck Society. 


\section{LITERATURE CITED}

Alfreider A, Pernthaler J, Amann R, Sattler B, Glöckner FO, Wille A, Psenner R (1996) Community analysis of the bacterial assemblages in the winter cover and pelagic layers of a high mountain lake by in situ hybridization. Appl Environ Microbiol 62:2138-2144

Andersson A, Larsson U, Hagström ^̊ (1986) Size-selective grazing by a microflagellate on pelagic bacteria. Mar Ecol 33:51-57

Bratbak G, Thingstad TF (1985) Phytoplankton-bacteria interactions: an apparent paradox? Analysis of a model system with both competition and commensalism. Mar Ecol Prog Ser 25:23-30

Brümmer IHM, Felske A, Wagner-Döbler I (2003) Diversity and seasonal variability of beta-Proteobacteria in biofilms of polluted rivers: analysis by temperature gradient gel electrophoresis and cloning. Appl Environ Microbiol 69: 4463-4473

Burkert U, Warnecke F, Babenzien D, Zwirnmann E, Pernthaler J (2003) Members of a readily enriched $\beta$-Proteobacterial clade are common in surface waters of a humic lake. Appl Environ Microbiol 69:6550-6559

Cleven EJ, Weisse T (2001) Seasonal succession and taxonspecific bacterial grazing rates of heterotrophic nanoflagellates in Lake Constance. Aquat Microb Ecol 23:147-161

Daims H, Bruhl A, Amann R, Schleifer KH, Wagner M (1999) The domain-specific probe EUB338 is insufficient for the detection of all Bacteria: development and evaluation of a more comprehensive probe set. Syst Appl Microbiol 22: 434-444

Eccleston-Parry JD, Leadbeater BSC (1995) Regeneration of phosphorus and nitrogen by four species of heterotrophic nanoflagellates feeding on three nutritional states of a single bacterial strain. Appl Environ Microbiol 61:1033-1038

Gasol JM, Comerma M, Garcia JC, Armengol J, Casamayor EO, Kojacká P, Šimek K (2002) A transplant experiment to identify the factors controlling bacterial abundance, activity, production, and community composition in a eutrophic canyon-shaped reservoir. Limnol Oceanogr 47:62-77

Glöckner FO, Amann R, Alfreider A, Pernthaler J, Psenner R, Trebesius K, Schleifer KH (1996) An in situ hybridization protocol for detection and identification of planktonic bacteria. Syst Appl Microbiol 19:403-406

Glöckner FO, Fuchs BM, Amann R (1999) Bacterioplankton compositions of lakes and oceans: a first comparison based on fluorescence in situ hybridization. Appl Environ Microbiol 65:3721-3726

Glöckner FO, Zaichikov E, Belkova N, Denissova L, Pernthaler J, Pernthaler A, Amann R (2000) Comparative 16S rRNA analysis of lake bacterioplankton reveals globally distributed phylogenetic clusters including an abundant group of Actinobacteria. Appl Environ Microbiol 66: 5053-5065

Güde H (1989) The role of grazing on bacteria in plankton succession. In: Sommer U (ed) Plankton ecologys succession in plankton communities. Springer Verlag, Berlin, p 337-364

Guillard RRL, Lorenzen CJ (1972) Yellow-green algae with chlorophyllide c. J Phycol 8:10-14

Hahn M, Höfle MG (1999) Flagellate predation on a bacterial model community: interplay of size-selective grazing, specific bacterial cell size, and bacterial community composition. Appl Environ Microbiol 65:4863-4872

Hahn M, Höfle MG (2001) Grazing of protozoa and its effect on populations of aquatic bacteria. FEMS Microbiol Ecol 35:113-121
Hahn MW, Lunsdorf H, Janke L (2004) Exopolymer production and microcolony formation by planktonic freshwater bacteria: defence against protistan grazing. Aquat Microb Ecol 35:297-308

Jürgens K, Matz C (2002) Predation as a shaping force for the phenotypic and genotypic composition of planktonic bacteria. Anton Leeuw Int J Gen Mol Microbiol 81:413-434

Jürgens K, Pernthaler J, Schalla S, Amann R (1999) Morphological and compositional changes in a planktonic bacterial community in response to enhanced protozoan grazing. Appl Environ Microbiol 65:1241-1250

Kalmbach S, Manz W, Wecke J, Szewzyk U (1999) Aquabacterium gen. nov., with description of Aquabacterium citratiphilum sp. nov., Aquabacterium parvum sp. nov. and Aquabacterium commune sp. nov., three in situ dominant bacterial species from the Berlin drinking water system. Int J Syst Bacteriol 49:769-777

Klammer S, Posch T, Sonntag B, Griebler C, Mindl B, Psenner R (2002) Dynamics of bacterial abundance, biomass, activity, and community composition in the oligotrophic Traunsee and the Traun river (Austria). Water Air Soil Poll Focus 2:137-163

Langenheder S, Jürgens K (2001) Regulation of bacterial biomass and community structure by metazoan and protozoan predation. Limnol Oceanogr 46:121-134

Loferer-Krößbacher M, Klima J, Psenner R (1998) Determination of bacterial cell dry mass by transmission electron microscopy and densiometric image analysis. Appl Environ Microbiol 64:668-694

Mašín M, Jezbera J, Nedoma J, Straškrabová V, Hejzlar J, Šimek K (2003) Changes in bacterial community composition and microbial activities along the longitudinal axis of two canyon-shaped reservoirs with different nutrient loading. Hydrobiologia 504:99-113

Massana R, Gasol JM, Bjørsen PK, Blackburn N and 5 others (1997) Measurement of bacterial size via image analysis of epifluorescence preparations: description of an inexpensive system and solutions to some of the most common problems. Sci Mar 61:397-407

Menden-Deuer S, Lessard EJ (2000) Carbon to volume relationships for dinoflagellates, diatoms, and other protist plankton. Limnol Oceanogr 45:569-579

Methé BA, Zehr JP (1999) Diversity of bacterial communities in Adirondack lakes: do species assemblages reflect lake water chemistry? Hydrobiologia 401:77-96

Mindl B, Sonntag B, Pernthaler J, Vrba J, Psenner R, Posch T (2005) Effects of phosphorus loading on interactions of algae and bacteria: reinvestigation of the 'phytoplanktonbacteria paradox' in a continuous cultivation system. Aquat Microb Ecol 38:203-213

Neef A (1997) Anwendung der in situ Einzelzell-Identifizierung von Bakterien zur Populationsanalyse in komplexen mikrobiellen Biozönosen. PhD thesis, Technical University, Munich

Pernthaler J, Sattler B, Šimek K, Schwarzenbacher A, Psenner R (1996) Top-down effects on the size-biomass distribution of a freshwater bacterioplankton community. Aquat Microb Ecol 10:255-263

Pernthaler J, Posch T, Šimek K, Vrba J, Amann R, Psenner R (1997) Contrasting bacterial strategies to coexist with a flagellate predator in an experimental microbial assemblage. Appl Environ Microbiol 63:596-601

Pernthaler J, Posch T, Šimek K, Vrba J and 5 others (2001) Predator-specific enrichment of Actinobacteria from a cosmopolitan freshwater clade in mixed continuous culture. Appl Environ Microbiol 67:2145-2155

Pernthaler A, Pernthaler J, Amann R (2002) Fluorescence in 
situ hybridization and catalyzed reporter deposition for the identification of marine bacteria. Appl Environ Microbiol 68:3094-3101

Poindexter JS, Pujara KP, Staley JT (2000) In situ reproductive rate of freshwater Caulobacter ssp. Appl Environ Microbiol 66:4105-4111

Posch T, Pernthaler J, Alfreider A, Psenner R (1997) Cellspecific respiratory activity of aquatic bacteria studied with the tetrazolium reduction method, cyto-clear slides, and image analysis. Appl Environ Microbiol 63:867-873

Posch T, Šimek K, Vrba J, Pernthaler J, Nedoma J, Sattler B, Sonntag B, Psenner R (1999) Predator-induced changes of bacterial size-structure and productivity studied on an experimental microbial community. Aquat Microb Ecol 18: 235-246

Posch T, Jezbera J, Vrba J, Šimek K, Pernthaler J, Andreatta S, Sonntag B (2001) Size selective feeding in Cyclidium glaucoma (Ciliophora, Scuticociliatida) and its effects on bacterial community structure: a study from a continuous cultivation system. Microb Ecol 42:217-227

Rothhaupt KO (1996a) Utilization of substitutable carbon and phosphorus sources by the mixotrophic chrysophyte Ochromonas sp. Ecology 77:706-715

Rothhaupt KO (1996b) Laboratory experiments with a mixotrophic chrysophyte and obligately phagotrophic and phototrophic competitors. Ecology 77:716-724

Rothhaupt KO (1997) Nutrient turnover by freshwater bacterivorous flagellates: differences between a heterotrophic and a mixotrophic chrysophyte. Aquat Microb Ecol 12:65-70

Sanders RW, Porter KG, Bennett SJ, DeBiase AE (1989) Seasonal patterns of bacterivory by flagellates, ciliates, rotifers, and cladocerans in a freshwater planktonic community. Limnol Oceanogr 34:673-687

Sekar R, Pernthaler A, Pernthaler J, Warnecke F, Posch T,

Editorial responsibility: David Caron,

Los Angeles, California, USA
Amann R (2003) An improved protocol for quantification of freshwater Actinobacteria by fluorescence in situ hybridization. Appl Environ Microbiol 69:2928-2935

Sherr EB, Sherr BF (1993) Preservation and storage of samples for enumeration of heterotrophic protist. In: Sherr EB, Sherr BF, Kemp P (eds) Handbook of methods in aquatic microbial ecology. Lewis Publishers, Boca Raton, FL, p 207-212

Šimek K, Vrba J, Pernthaler J, Posch T, Hartman P, Nedoma J, Psenner R (1997) Morphological and compositional shifts in an experimental bacterial community influenced by protists with contrasting feeding modes. Appl Environ Microbiol 63:587-595

Šimek K, Kojacká P, Nedoma J, Hartman P, Vrba J, Dolan JR (1999) Shifts in bacterial community composition associated with different microzooplankton size fractions in a eutrophic reservoir. Limnol Oceanogr 44:1634-1644

Šimek K, Armengol J, Comerma M, Garcia JC, Kojacká P, Nedoma J, Hejzlar J (2001a) Changes in the epilimnetic bacterial community composition, production, and protistinduced mortality along the longitudinal axis of a highly eutrophic reservoir. Microb Ecol 42:359-371

Šimek K, Pernthaler J, Weinbauer MG, Horňák K, Dolan JR, Nedoma J, Mašín M, Amann R (2001b) Changes in bacterial community composition and dynamics and viral mortality rates associated with enhanced flagellate grazing in a mesoeutrophic reservoir. Appl Environ Microbiol 67: $2723-2733$

Šimek K, Horňák K, Mašín M, Christaki U, Nedoma J, Weinbauer MG, Dolan JR (2003) Comparing the effects of resource enrichment and grazing on a bacterioplankton community of a meso-eutrophic reservoir. Aquat Microb Ecol 31:123-135

Sommaruga R, Psenner R (1995) Trophic interactions within the microbial food web in Piburger See (Austria). Arch Hydrobiol 132:257-278

Submitted: August 2, 2004; Accepted: December 16, 2004 Proofs received from author: February 28, 2005 